Original Research Article

\title{
Effect of Trigonella foenum (methi) on fasting blood glucose levels in alloxan induced diabetes in rabbits
}

\author{
Ghulam Subhani*, Ayesha Vaseem
}

\begin{abstract}
Department of Pharmacology, Osmania Medical College, Hyderabad, Telangana, India
\end{abstract}

Received: 29 September 2016 Accepted: 27 October 2016

\section{*Correspondence to: \\ Dr. Ghulam Subhani, \\ Email: subhanis_2000@ yahoo.com}

Copyright: (C) the author(s), publisher and licensee Medip Academy. This is an openaccess article distributed under the terms of the Creative Commons Attribution NonCommercial License, which permits unrestricted noncommercial use, distribution, and reproduction in any medium, provided the original work is properly cited.

\begin{abstract}
Background: Water-retaining fibers, especially the mucilaginous compounds, such as the gel fiber present in Fenugreek seeds, reduce the rate of glucose absorption and may also delay gastric emptying thereby preventing the rise in blood sugar levels following a meal. In addition to its hypoglycemic effects, the hyperlipidemic effect of Fenugreek fibers has also been documented. The objective of the study was to study the effect of Trigonella foenum (methi) on Fasting Blood Glucose levels in Alloxan induced diabetes in Rabbits.

Methods: Fenugreek seed extract was prepared. Study was carried out on alloxan induced diabetic rabbits. They were prepared for the study. Then they were grouped into 5 groups depending upon the drugs used for them. The drug solutions were prepared and administered to diabetic rabbits. The blood sugar levels were recorded before and after treatment for first 15 days and once in week for next three weeks. Daily fasting blood sugar readings were taken. The blood glucose was determined with standard procedures and methods.

Results: Alcohol extract of fenugreek seeds using soxhlet apparatus produced significant $(\mathrm{P}<0.001)$ reduction in the blood glucose levels in the alloxan induced diabetic rabbits in the 3 doses i.e. $0.5 \mathrm{gm} / \mathrm{kg}, 1 \mathrm{gm} / \mathrm{kg}$ and $1.5 \mathrm{gm} / \mathrm{kg}$ body weight after oral administration compared to the vehicle treated group ( 5 $\mathrm{ml}$ of $2 \%$ gum acacia) over the period of 5 weeks. The standard oral antidiabetic drug (Metformin) in the dose of $62.5 \mathrm{mg} / \mathrm{kg}$ body weight also reduced the blood glucose level in the Alloxan induced diabetic rabbits over 5 weeks period of treatment compared to vehicle group. ( $5 \mathrm{ml}$ of $2 \%$ gum acacia).

Conclusions: All the three doses of Trigonella foenum significantly $(\mathrm{P}<0.001)$ reduced blood glucose levels in Alloxan induced diabetic rabbits over a period of 5 weeks in comparison to vehicle ( $5 \mathrm{ml}$ of $2 \%$ of gum acacia) orally.
\end{abstract}

Keywords: Alloxan, Rabbits, Trigonella foenum

\section{INTRODUCTION}

Diabetes mellitus is the world's largest endocrine disease resulting in disordered metabolism, usually due to a combination of hereditary and environmental causes, resulting in abnormally high blood sugar levels (hyperglycemia) due to defects in either insulin secretion or insulin action in the body. ${ }^{1}$

In 2000, according to the World Health Organization, at least 171 million people worldwide suffer from diabetes, or $2.8 \%$ of the population. Its incidence is increasing rapidly, and it is estimated that by the year 2030, this number will almost double. ${ }^{2}$

Diabetes mellitus prevalence increases with age, and the numbers of older persons with diabetes are expected to grow as the elderly population increases in number. The National Health and Nutrition Examination Survey (NHANES III) demonstrated that, in the population over 65 years old, $18 \%$ to $20 \%$ have diabetes, with $40 \%$ having either diabetes or its precursor form of impaired glucose tolerance. ${ }^{3}$

In Fenugreek seeds, the gum (gel fiber) fraction consists of galactomannan which is made up of galactose and mannose units. The gum also resembles guar gum in structure and is very viscous when dissolved in water. The neutral detergent fiber is made up of indigestible carbohydrates such as cellulose, hemicellulose and lignin. Low digestibility indicates better fiber functionality, with lower incidence of gastrointestinal disturbances such as bloating due to fermentation by gastrointestinal microflora. ${ }^{4}$ 
A high-fiber diet is associated with the improved ability to handle blood sugar. In the presence of a high fiber diet, the cells are more sensitive to insulin and an increase in the number of insulin receptor sites occurs or alternatively, there is a stimulation of the cell's ability to burn glucose. Certain dietary fibers reduce the rate of food passage through the intestine and into the bloodstream, thereby helping to control the increase in postprandial blood sugar levels. High-fiber diets are associated with less glycosuria (sugar in urine), lower fasting blood sugar levels, and lower insulin requirements. Water-retaining fibers, especially the mucilaginous compounds, such as the gel fiber present in Fenugreek seeds, reduce the rate of glucose absorption and may also delay gastric emptying thereby preventing the rise in blood sugar levels following a meal. In addition to its hypoglycemic effects, the hypolipidemic effect of Fenugreek fibers has also been documented. Therefore, Fenugreek fibers have a dual role to play in the management of diabetes. ${ }^{3}$

Present study was carried out to study the effect of Trigonella foenum (methi) on Fasting Blood Glucose levels in Alloxan induced diabetes in Rabbits.

\section{METHODS}

\section{Preparation of fenugreek seed extract}

Requirements: Fenugreek seeds, Soxhlet apparatus, Alcohol (Absolute 99.9\%) Supplied by Jiangsu Huaxi From China International Trade Co Ltd., Electric grinder

\section{Preparation of extract}

PLANT MATERIALS: Seeds of Fenugreek popularly known as Methi was obtained in sufficient quantity from government Ayurvedic hospital, Rajender Nagar, Hyderabad, AP. They were carefully washed to remove dust particles and other foreign materials and dried in shaded area. The completely dried seeds were powdered with electric grinder and stored in well closed bottles.

\section{Alcohol - extract preparation}

The extract is a concentrated preparation of vegetables or animal source.

Extract: The extract is the process or act of pulling or drawing out the active principle of a particular material like plants, seeds or animal organs.

Methods: The extraction methods are mainly two types.

- Macceration method.

- Percolation method.

In the present study the percolation method was selected to extract the active principle of fenugreek seeds.
Cold percolation method: This is a traditional method of extraction used by the herbalists throughout the world. This is the original extraction method, and it continuous to be the backbone of the present extracting technology. The distillation devices are "modified Soxhlet extractions" made by Eden Labs. A Soxhlet extractor is a piece of laboratory apparatus invented in 1879 by Franz von Soxhlet.

Table 1: Grouping of rabbits.

\begin{tabular}{|c|c|c|c|}
\hline Groups & Animals & Drug & $\begin{array}{l}\text { Name of } \\
\text { the group }\end{array}$ \\
\hline I & $\begin{array}{l}\text { Negative } \\
\text { control }\end{array}$ & $\begin{array}{l}2 \% \text { gum } \\
\text { acacia: } 5 \mathrm{ml}\end{array}$ & Placebo \\
\hline II & $\begin{array}{l}\text { Test low } \\
\text { dose }(0.5 \\
\text { gm })\end{array}$ & $\begin{array}{l}\text { Alcohol extract } \\
+2 \% \text { gum } \\
\text { acacia: } 5 \mathrm{ml}\end{array}$ & ExL \\
\hline III & $\begin{array}{l}\text { Medium } \\
\text { dose (1 gm) }\end{array}$ & $\begin{array}{l}\text { Alcohol extract } \\
+2 \% \text { gum } \\
\text { acacia: } 5 \mathrm{ml}\end{array}$ & ExM \\
\hline IV & $\begin{array}{l}\text { High dose } \\
(1.5 \mathrm{gm})\end{array}$ & $\begin{array}{l}\text { Alcohol extract } \\
+2 \% \text { gum } \\
\text { acacia: } 5 \mathrm{ml}\end{array}$ & ExH \\
\hline V & $\begin{array}{l}\text { Positive } \\
\text { control }\end{array}$ & $\begin{array}{l}\text { Metformin } \\
62.5 \mathrm{mg} / \mathrm{kg}+ \\
2 \% \text { gum } \\
\text { acacia: } 5 \mathrm{ml}\end{array}$ & Met \\
\hline
\end{tabular}

\section{Procedure}

\section{Principle}

Within an enclosed flask there is an inverted condenser pointing down into the flask from the top. Just below that condenser will be suspended either what's called a soxhlet basket or a recovery vessel depending on whether you're extracting or recovering solvent. The condenser will have cold liquid circulating through it to keep the condenser cold. In the bottom of the main flask solvent is placed. To do an extraction, the ground plant material is placed in the soxhlet basket, which is a vessel with perforated sides and bottom so that liquid can fall through it. When gentle heat is applied to the main flask, the solvent begins to evaporate and the solvent vapors reach the cold condenser at the top of the flask and begin to liquefy on the sides of the condenser. (Much the same way that a cold glass of water becomes wet on the outside of itself on a hot day) The re-condensed solvent on the sides of the condenser begin flowing down the sides of the condenser and begin dripping off of drip points on the end of the condenser. This solvent drips into the top of the soxhlet basket where it saturates the herb being extracted. The solvent flows through the basket and out of the holes in the bottom of the basket carrying the extract with it into the bottom of the flask. The extract laden solvent falling from the soxhlet basket is dark in color and as it becomes clearer you know that the plant material is leached out and the process is finished. 


\section{Extraction procedure}

- The dried fine powder of the fenugreek seeds were weighed on balance $25 \mathrm{~g}$. and taken into the sac like cloth material and placed in the Soxhlet basket.

- $250 \mathrm{ml}$ of ethyl alcohol was taken as solvent into the Soxhlet flask.

- Cold tap water must flow through the inlet and outlet of the condenser.

- The Soxhlet apparatus keep in running for 24 hours for proper extraction.

- The extract laden solvent falling from the soxhlet basket is dark in color and it becomes clearer, that indicates the extraction process is finished. ${ }^{5}$

- At the end of the extraction process the solvent is then evaporated and the remaining mass is measured.

The yield of the ethyl alcohol extract is $20 \%$. The extract was suspended in $5 \mathrm{ml}$ of $2 \%$ Gum acacia and used for the oral administration in diabetic rabbits.

\section{Animals used}

30 Rabbits of either sex, adult, healthy albino rabbits of local strain weighing between 1 to $4 \mathrm{~kg}$ were used in this experiment. All the animals were kept in an air-cooled animal house of the Pharmacology department at Kamineni Institute of Medical Sciences, Narketpally, Nalgonda, and AP. The animals, rabbits were offered a natural food like grass and leave and allowed a tap water to drink.

\section{Preparation of diabetic rabbits}

Requirements: Alloxan (Rolex - Mumbai), Distilled water, Scalp vein set (Romson's) it is used for giving alloxan through ear vein of the rabbit. Size NG-24, Xylene (Rectified) supplied by Qualigens fine chemicals Mumbai), Dextrose anhydrous - supplied by Thomas Baker Chemical Ltd. Mumbai.

The 25 rabbits weighing between 1 to $4 \mathrm{~kg}$ were made diabetic by injecting intravenously $150 \mathrm{mg} / \mathrm{kg}$ body weight of Alloxan monohydrate. Before giving Alloxan, the normal blood glucose levels of all rabbits were estimated. After 2 hours of Alloxan injection the Dextrose (5 gm) mixed with water fed to the all-diabetic rabbits orally to prevent hypoglycemic condition of rabbits with alloxan.

After 72 hours of alloxan injection, the blood glucose levels of all surviving rabbits were determined by the glucose oxidase method. The rabbits with blood glucose levels of 220 to $500 \mathrm{mg} / \mathrm{dl}$ were considered as diabetic and were employed for further study. ${ }^{6}$

\section{Grouping of rabbits}

All alloxan diabetic rabbits were randomly divided into five groups (1-5) of six animals each.

For all the diabetic rabbits after giving test, negative control and positive control preparations, the animals were kept fasting with only water for $16 \mathrm{hrs}$ and blood samples were collected and fasting blood glucose levels were determined the next day.

\section{Preparation of drug solutions}

- Alloxan $-150 \mathrm{mg} / \mathrm{ml}^{7} 0.5 \mathrm{gm}$ of alloxan is dissolved in $3.3 \mathrm{ml}$ of distilled water.

- Metformin $(500 \mathrm{mg})-62.5 \mathrm{mg} / \mathrm{ml} .{ }^{8}$ One tablet contains $500 \mathrm{mg}$ of metformin is dissolved in water.

- $2 \%$ Gum acacia- $2 \mathrm{gm}$ of Gum acacia is dissolved in $100 \mathrm{ml}$ of water. ${ }^{9}$

- Absolute alcohol (99.9\%) for extraction. ${ }^{9}$

- $250 \mathrm{ml}$ of alcohol taken as solvent for $25 \mathrm{gm}$ of methi seed powder.

\section{Drug administration}

\section{Requirement}

Infant feeding tube (Romson's) for gastric feeding of extracts and drugs to the rabbit, $5 \mathrm{ml}$ syringes, and Glycerin

The prepared drugs were administered to the test groups, control group and standard group of rabbits.

The amount of fenugreek seed extract required for test group animals was calculated on body weight basis. The required extract was well triturated with $5 \mathrm{ml}$ of $2 \%$ Gum acacia and the final volume is given to the diabetic rabbits orally for treatment purpose.

For negative control rabbits, $5 \mathrm{ml}$ of $2 \%$ Gum acacia was given orally.

The positive control rabbits (standard) were given by $62.5 \mathrm{mg} / \mathrm{kg}$ of metformin in $5 \mathrm{ml}$ solution orally.

All the rabbits including (test, negative control, and standard) were given with respected treatment drugs orally by using infant feeding tube on a plastic syringe containing the $5 \mathrm{ml}$ of suspension.

The tube was moistened with glycerin and inserted into the stomach through esophagus and the plunger was pressed slowly and steadily. Immediate sneezing and 
coughing indicates injection into the lungs and in such conditions the tube is at once withdrawn and another animal is taken instead. All groups (1-5) of rabbits were given with their respected treatment drugs daily once up to 35 days.

\section{Blood collection}

Requirements: Xylene, Needles (26 gauge), Cotton swab

\section{Determination of blood glucose}

Requirements: Glucometer (Accu-Check active) with reagent strips, Needles, Cotton swab.

After administration of drugs to the diabetic rabbits the blood was collected daily up to 35 days and blood glucose level (fasting) was determined with glucose oxidase method by using glucometer for 15 days and then weekly for 3 weeks. The glucose oxidase method is more accurate, rapid and time saving method. It requires only small amount of blood. So this method is popularly used in India people suffering from diabetes for selfmonitoring of blood glucose levels

\section{RESULTS}

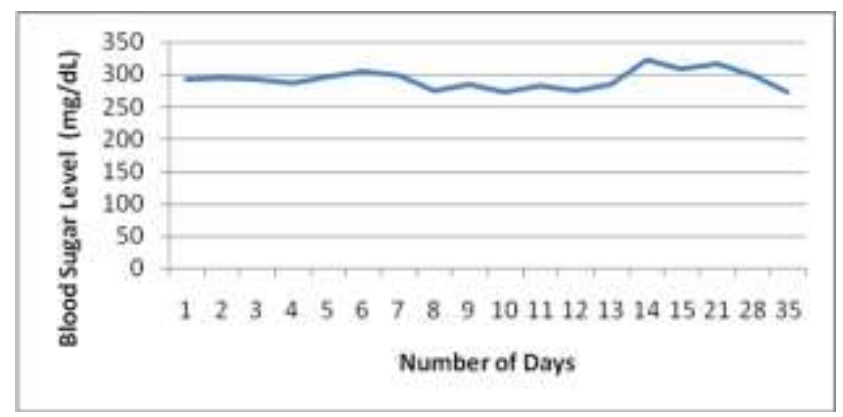

Figure 1: Placebo (The average blood sugar levels in the placebo group).

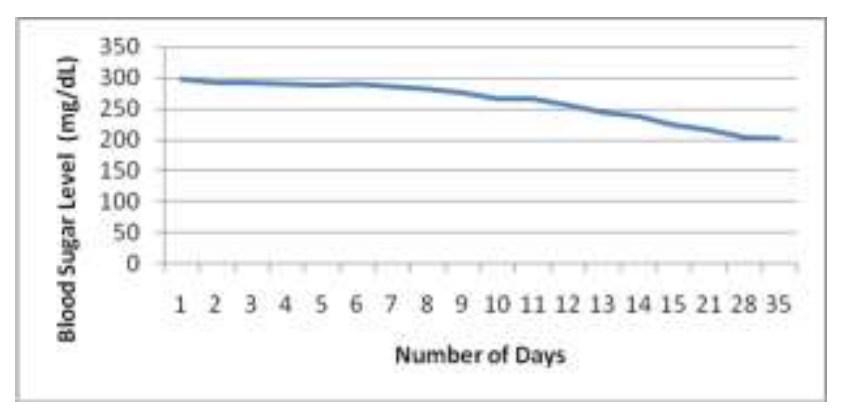

Figure 2: ExL (Average blood sugar levels in fenugreek extract in low dose group).

Alloxan induced diabetic rabbits were treated with gum acacia orally for 35 days. The blood sugar levels were recorded before and after treatment for first 15 days and once in week for next three weeks. Daily fasting blood sugar readings were taken. The initial blood sugar levels of the diabetic rabbits were maintained up to 35 days after treatment with gum acacia in this group of rabbits. There was no significant fall in the blood sugar levels.

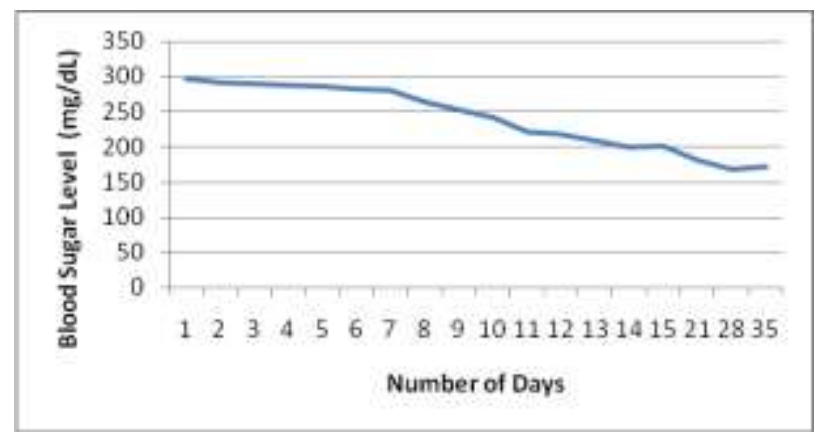

Figure 3: ExM (Average blood sugar levels in the fenugreek extract in medium dose group).

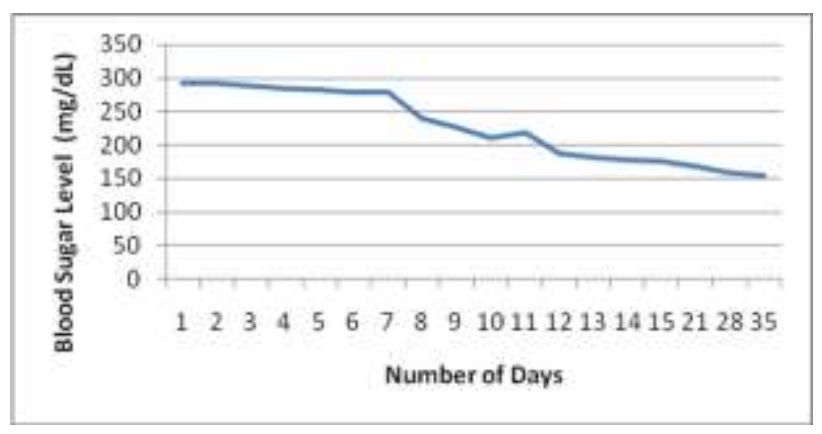

Figure 4: ExH (Average blood sugar levels in the fenugreek extract in high dose group).

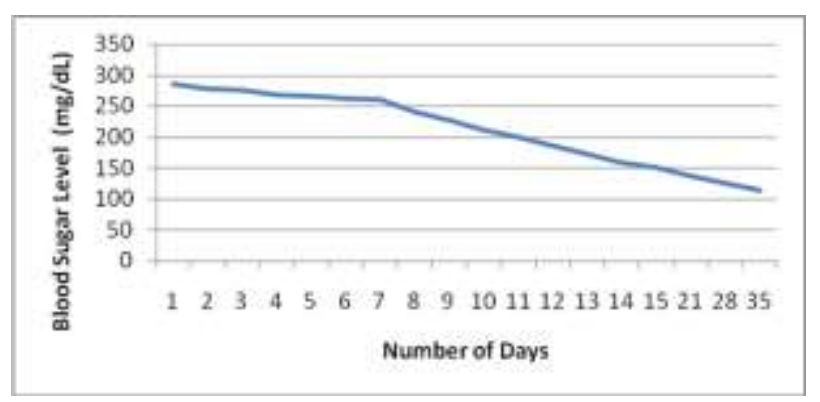

Figure 5: Metformin (Average blood sugar levels in the metformin group).

In the next step, alloxan induced diabetic rabbits treated with Fenugreek seed alcoholic extract given orally for 35 days in the low dose $(0.5 \mathrm{gm} / \mathrm{kg})(\mathrm{ExL})$. The blood levels were recorded before and after treatment for first 15 days and once in week for next three weeks. Significant fall in blood sugar levels was noticed.

The alloxan induced diabetic rabbits treated with Fenugreek seed powder alcoholic extract given orally for 35 days in the medium dose $(1.0 \mathrm{gm} / \mathrm{kg})$. (ExM) The blood levels were recorded before and after treatment for first 15 days and once in week for next three weeks. 
Significant fall in blood sugar levels was noticed over the five weeks period.

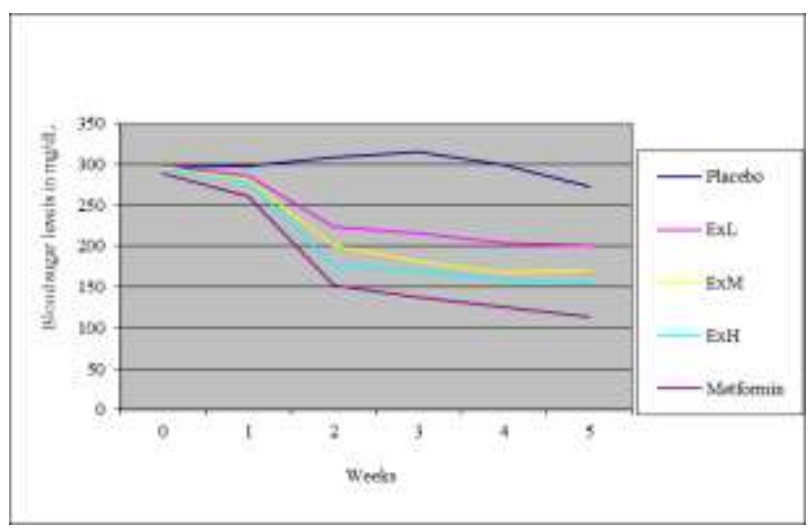

Figure 6: Cumulative comparison of different groups.

Area under curve was done using the trapezoidal rule which is a numerical method to be used to approximate the integral or the area under a curve. Using trapezoidal rule to approximate the area under a curve first involves dividing the area into a number of strips of equal width. Then, approximating the area of each strip by the area of the trapezium formed when the upper end is replaced by a chord. The sum of these approximations gives the final numerical result of the area under the curve.

Calculation of AUC using the trapezoidal rule was done using the formula

Auc $=1 / 2 \sum_{i} " 0,{ }^{n-1}\left(t_{i+1}-t_{i}\right) X\left(y_{i}+y_{i+1}\right)$

Analysis of variation (ANOVA) (Table 1) enables to compare the means of three or more variables unlike the ' $t$ ' test where the means of only two variables can be compared the test (ANOVA) compares the variations in the mean between the treatments and those within the treatments. A significantly larger between variations indicates a significant difference between them. ANOVA gives the differences between the mean in the experiment as a whole, and not which treatments differ from one another.

To find out the difference among the groups multiple comparison tests was done using Scheffe's and Dunnet's test.

AUC was taken for all the rabbits in the Metformin group $(62.5 \mathrm{mg} / \mathrm{kg})$ where

$\mathrm{X}$ axis is the number of days the blood sugar levels were checked

$\mathrm{Y}$ axis is the measurement of blood glucose levels in $\mathrm{mg} / \mathrm{dL}$

In the last group, the alloxan induced diabetic rabbits treated with Fenugreek seed alcoholic extract given orally for 35 days in the high dose $(1.5 \mathrm{gm} / \mathrm{kg})$. (ExH) The blood levels were recorded before and after treatment for first 15 days and once in week for next three weeks. Significant fall in blood sugar levels was noticed over the five weeks period.

Table 2: AUC of blood glucose (mg/dL) level.

\begin{tabular}{|llllll|}
\hline Rabbit & Placebo & ExL & ExM & ExH & Met \\
\hline 1 & 10807.0 & 8426.5 & 7382.5 & 6981.0 & 6264.5 \\
\hline 2 & 9628.0 & 8602.5 & 7699.0 & 7149.0 & 6090.5 \\
\hline 3 & 10573.5 & 8520.0 & 7846.5 & 7085.5 & 6426.0 \\
\hline 4 & 10651.5 & 8485.5 & 7932.0 & 7115.0 & 6068.0 \\
\hline 5 & 11611.5 & 8928.5 & 7513.5 & 7555.0 & 6514.0 \\
\hline 6 & 10178.0 & 8234.0 & 7287.0 & 7008.5 & 6619.5 \\
\hline
\end{tabular}

Area under Curve was determined for placebo, different doses of extract and standard anti-diabetic drug metformin.

Table 3: Overall comparison between different groups of rabbits (One-Way ANOVA).

\begin{tabular}{|lll|lll|l|}
\hline Source & S.S & df & MS & F & P & Sig \\
\hline Between & 63420421.22 & 4 & 15855105.30 & 121.55 & P $<0.001$ & $* * *$ \\
\hline Within & 3260946.46 & 25 & 130437.86 & & & \\
\hline Total & 66681367.68 & 29 & & & & \\
\hline
\end{tabular}

It was found that there was significant variation $(\mathrm{P}<0.01)$ in the blood sugar levels among the groups.

Table 1 indicates the standard drug Metformin action on rabbits. The metformin used as standard drug in the dose of $62.5 \mathrm{mg} / \mathrm{kg}$ body weight given orally for alloxan induced diabetic rabbits for 35 days. The blood levels were recorded before and after treatment with metformin for first 15 days and once in week for next three weeks.
As expected, significant fall in blood sugar levels was noticed over the five week period.

Significant $(\mathrm{P}<0.001)$ difference was found between placebo and all doses of test drug. Difference is significant $(\mathrm{P}<0.001)$ between all doses of test and metformin. No significant $(\mathrm{P}>0.05)$ difference between medium and high dose of test drugs. 


\section{DISCUSSION}

In the present study alcohol extract of fenugreek seeds using soxhlet apparatus produced significant $(\mathrm{P}<0.001)$ reduction in the blood glucose levels in the alloxan induced diabetic rabbits in the 3 doses i.e. $0.5 \mathrm{gm} / \mathrm{kg}, 1$ $\mathrm{gm} / \mathrm{kg}$ and $1.5 \mathrm{gm} / \mathrm{kg}$ body weight after oral administration compared to the vehicle treated group (5 $\mathrm{ml}$ of $2 \%$ gum acacia) over the period of 5 weeks.

Table 4: Multiple comparison test (Post-Hoc Test): critical values.

\begin{tabular}{|lll|}
\hline alpha & Scheffe's test & Dunnet's test \\
\hline 0.05 & 692.67 & 544.23 \\
\hline 0.01 & 852.36 & 692.28 \\
\hline 0.001 & 1062.66 & - \\
\hline
\end{tabular}

\begin{tabular}{|llll|}
\hline Comparison & $\begin{array}{l}\text { Difference } \\
\text { between } \\
\text { Mean AUC }\end{array}$ & $\begin{array}{l}\text { Scheffe's } \\
\text { test }\end{array}$ & $\begin{array}{l}\text { Dunnet's } \\
\text { Test }\end{array}$ \\
\hline Placebo vs. ExL & 2042.08 & $\mathrm{P}<0.001$ & $\mathrm{P}<0.001$ \\
\hline $\begin{array}{l}\text { Placebo vs. } \\
\text { ExM }\end{array}$ & 2964.83 & $\mathrm{P}<0.001$ & $\mathrm{P}<0.001$ \\
\hline $\begin{array}{l}\text { Placebo vs. } \\
\text { ExH }\end{array}$ & 3425.92 & $\mathrm{P}<0.001$ & $\mathrm{P}<0.001$ \\
\hline Placebo vs. Met & 4244.50 & $\mathrm{P}<0.001$ & $\mathrm{P}<0.001$ \\
\hline ExL vs.ExM & 922.75 & $\mathrm{P}<0.01$ & \\
\hline ExL vs.ExH & 1383.83 & $\mathrm{P}<0.001$ & \\
\hline ExL vs. Met & 2202.42 & $\mathrm{P}<0.001$ & \\
\hline ExM vs. ExH & 461.08 & $\mathrm{P}>0.05$ & \\
\hline ExM vs. Met & 1279.67 & $\mathrm{P}<0.001$ & \\
\hline ExH vs. Met & 818.58 & $\mathrm{P}<0.05$ & \\
\hline
\end{tabular}

The standard oral anti diabetic drug (Metformin) in the dose of $62.5 \mathrm{mg} / \mathrm{kg}$ body weight also reduced the blood glucose level in the Alloxan induced diabetic rabbits over 5 weeks period of treatment compared to vehicle group. ( $5 \mathrm{ml}$ of $2 \%$ gum acacia).

AUC (Area under Curve) comparison between the test drug and Metformin showed significant $(\mathrm{P}<0.001)$ difference at all doses of test drug.

Abdel-Barry JA et $\mathrm{al}^{10}$, Vats $\mathrm{V}$ et $\mathrm{al}^{11}$, Khosla $\mathrm{P}$ et $\mathrm{al}^{12}$ also reported oral hypoglycemic effect of fenugreek in alloxan induced diabetic rats.

Xue WL et $\mathrm{al}^{13}$, Tayyaba Zia et $\mathrm{al}^{14}$ also reported oral hypoglycemic effect of fenugreek in streptozotocin induced diabetic rats.

Hence, our results of blood glucose lowering effect of alcoholic extract of fenugreek seeds in Alloxan induced diabetic rabbits are in concurrence to Abdel-Barry JA et $\mathrm{al}^{10}$, Vats $\mathrm{V}$ et $\mathrm{al}^{11}$, Khosla $\mathrm{P}$ et $\mathrm{al}^{12}$, Xue WL et $\mathrm{al}^{13}$, Tayyaba Zia et $\mathrm{al}^{14}$ in alloxan induced diabetic rats.
Further studies are required to elucidate the mechanism of action of fenugreek in lowering the blood glucose level in alloxan induced diabetic rabbits.

\section{CONCLUSION}

Trigonella foenum is taken traditionally for control of diabetes in India and in other countries for a long time. Three doses of alcohol extract of fenugreek seed powder was administered in 3 groups of alloxan induced diabetes in rabbits.

All the three doses significantly $(\mathrm{P}<0.001)$ reduced blood glucose levels in Alloxan induced diabetic rabbits over a period of 5 weeks in comparison to vehicle $(5 \mathrm{ml}$ of $2 \%$ of gum acacia) orally.

The standard oral anti-diabetic drug Metformin also produced significant reduction in blood glucose levels in the Alloxan induced diabetic rabbits over the 5 week treatment period.

AUC of blood glucose levels in Metformin treated group is significantly different than fenugreek treatment group.

Further studies are required to elucidate the mechanism of action of fenugreek seed extract in lowering the blood glucose levels in the Alloxan induced diabetic rabbits.

Funding: No funding sources

Conflict of interest: None declared

Ethical approval: The study was approved by the Institutional Ethics Committee

\section{REFERENCES}

1. Rother KI. Diabetes treatment - bridging the divide. N Engl J Med. 2007;356 (15):1499-501.

2. Chang AM, Halter JB. Aging and insulin secretion. Am J Physiol Endocrinol Metab. 2003;284(1):E7-12.

3. Cohen RV, Schiavon CA, Pinheiro JS et al. Duodenal-jejunal bypass for the treatment of type 2 diabetes in patients with body mass index of 22-34 $\mathrm{kg} / \mathrm{m} 2$ : a report of 2 cases". Surg Obes Relat Dis. 2007;3(2):195-7.

4. Garti N. Fenugreek Gum. The magic fiber for an improved glucose response and cholesterol reduction. NutraCos. 2002;1(3):5-10.

5. Asli Semiz. Various extraction procedures. African $\mathbf{J}$ Biotechnol. 2007;6(3):273-7.

6. Shani JA. Hypoglycemic effect of Trigonella Foenum Graceum in Alloxan Diabetic rats. Arch Interval Pharmacodyn. 1974;210(1):27-37.

7. Akthar AK, Athar MA, Yakub M. Effect of Momordica Charantia on blood sugar level of Normal and Alloxan rabbits. Planta Med. 1981;42:205-12.

8. Ojiako OA, Nwanjo HU. Effects of pliaglitazone on atherogenic risk predictor indices of alloxan induced diabetic rabbits. Biokemistri. 2005;17(2):179-84. 
9. Babu V, Gangadevi T, Subram Oniam A. Antidiabetic activity of ethanol extract of cassia kleinii leaf in streptozotocin-induced diabetic rats and isolation of an active fraction and toxicity evaluation of the extract. Indian J Pharmacol. 2003;35(5):290-6.

10. Abdel-Barry JA, Abdel-Hassan IA, Al-Hakien MH. Hypoglycemic and antihyperglycemic effects of Trigonella foenum-graecum leaf in normal and alloxan induced diabetic rats. J Ethnopharmacol. 1997;58:149-55.

11. Vats V, Grover JK, Rathi SS. Evaluation of antihyperglycemic and hypoglycemic effect of Trigonella foenum-graecum Linn, Ocimum sanctum Linn and Pterocarpus marsupium Linn in normal and alloxanized diabetic rats. J Ethnopharmacol. 2002;79(1):95-100.

12. Khosla P, Gupta DD, Nagpal RK. Effect of Trigonella foenum graecum (Fenugreek) on blood glucose in normal and diabetic rats. Indian J Physiol Pharmacol. 1995;39(2):173-4.

13. Xue WL, Li XS, Zhang J et al. Effect of Trigonella foenum-graecum (fenugreek) extract on blood glucose, blood lipid and hemorheological properties in streptozotocin-induced diabetic rats. Asia Pac J Clin Nutr. 2007;16 Suppl 1:422-6.

14. Zia T, Hasnain SN, Hasan SK. Evaluation of the oral hypoglycaemic effect of Trigonella foenum-graecum L. (methi) in normal mice $\mathbf{J}$ Ethnopharmacol. 2001;75(2-3):191-5.

Cite this article as: Subhani G, Vaseem A. Effect of Trigonella foenum (methi) on fasting blood glucose levels in alloxan induced diabetes in rabbits. Int $\mathbf{J}$ Basic Clin Pharmacol 2016;5:2634-40. 